Robert Roche Olivar*

ORCID: 0000-0002-0796-5193

Sandra Rodriguez Gil**

ORCID: 0000-0001-9844-669X

Barcelona, Hiszpania

\title{
Prospołeczność inspirowana charyzmatem jedności Chiary Lubich. Przykład wykorzystania w przedszkolu
}

\author{
Prosociality Inspired by the Charism \\ of the Unity of Chiara Lubich. An Application \\ in the School of Childhood
}

Summary: This article presents two distinct parts. The first tries to answer the questions: How do spiritual or religious intuitions apply in life? Or, better, how do

* Prof. dr Robert Roche Olivar, emerytowany profesor na Wydziale Psychologii Uniwersytetu Autonomicznego w Barcelonie oraz dyrektor LIPA (Applied Prosocial Research Laboratory) na tymże uniwersytecie, strony internetowe: www.rocherobert.wordpress.com; www.lipa-net.org; www.prosocialidad.wordpress.com. Adres: Campus de Bellaterra, Universitat Autònoma de Barcelona, Postal Code: 08193, Spain; e-mail: robert.roche@uab.cat.

** Sandra Rodríguez Gil, specjalistka w zakresie edukacji przedszkolnej oraz wspólnotowego uczenia się, zajmuje się inteligencją wieloraką oraz inteligencją emocjonalną, dyrektor LIPA (Laboratori Investigació Prosocial Aplicada) na Uniwersytecie Autonomicznym w Barcelonie. Adres: Laboratori Investigació Prosocial Aplicada, Dep. Psicologia Bàsica, Evolutiva y de l'Educació, Universitat Autònoma Barcelona, Postal Code: 08193, Spain; e-mail:sm.rodriguez@movistar.es. 
certain evangelical passages come to pass when they pass through a structuring of a system of thought? What application characteristics can a certain charism have when analysed and experimentally applied from a scientific perspective and methodology? In this first part, we present a biographical and professional journey of an academic group that started from a concern and experience of a person, the first author, for about 38 years. This group was trying to develop a theoretical-application model initially originated in the educational field and currently active in various areas of human activity, responding to the spiritual charism of a contemporary woman recognised by an institution as universal by the church. The second part shows one of the last experiences of these applications in the educational field. This experience occurs specifically in the infantile age, which is a crucial stage to mark positive tracks in the development of the personality, as well as positive patterns for the later interpersonal and social relations that employ prosociality and cooperation with a very experimental methodology.

Keywords: prosociality; charism of unity; school of childhood; Applied Prosocial Research Laboratory; Participation Action Research.

Streszczenie: Artykuł składa się z dwóch części. W pierwszej podjęto próbę odpowiedzi na pytania: w jaki sposób duchowe lub religijne intuicje znajdują zastosowanie w życiu? Lub bardziej: co staje się z konkretnymi fragmentami ewangelicznymi, gdy przechodzą przez strukturę systemu myślenia? Jakie charakterystyczne cechy może uzyskać określony charyzmat, gdy analizuje się go i eksperymentalnie wprowadza w życie z naukowej perspektywy i metodologii? W pierwszej części przedstawiamy biograficzną i zawodową podróż grupy akademickiej, która rozpoczęła się od troski i doświadczenia osoby, pierwszego autora, około 38 lat wcześniej. Grupa ta starała się opracować model teoretyczno-aplikacyjny, początkowo osadzony w dziedzinie edukacji, a obecnie wprowadzany w różnych obszarach ludzkiej aktywności, odpowiadając na duchowy charyzmat współczesnej kobiety uznany przez Kościół za uniwersalny. Druga część prezentuje jedno z ostatnich doświadczeń owych aplikacji w dziedzinę edukacji. To doświadczenie odnosi się do wieku poniemowlęcym, który jest kluczowym momentem w kształtowaniu pozytywnych rysów w rozwoju osobowości, jak również w budowaniu pozytywnych wzorców dla późniejszych relacji interpersonalnych i społecznych, łącząc prospołeczność i współpracę z bardzo eksperymentalną metodologią.

Słowa kluczowe: prospołeczność; charyzmat jedności; przedszkole; badania w działaniu; Laboratorium Stosowanych Badań Prospołecznych. 
W 1981 r. na Uniwersytecie Autonomicznym w Barcelonie (UAB) narodziły się studium, badania oraz doświadczenie aplikacyjne, dla których punktem odniesienia była kategoria i koncepcja prospołeczności. Przez 37 lat inspirowała ona moje życie osobiste, rodzinne i zawodowe.

Termin „prospołeczność” odnosił się do koncepcji zachowań prospołecznych, którą w tym czasie wykorzystali dr Paul Musse i dr Nancy Eisenberg. Ich praca była jedną z pierwszych publikacji, w których pojawiło się pojęcie zachowań prospołecznych ${ }^{1}$.

W tym czasie (1981) jako profesor psychologii na Uniwersytecie Autonomicznym w Barcelonie szukałem tematu i linii badań, które mogłyby nadać kierunek mojej pracy, odnosząc się do pozytywnego rozwoju potencjału ludzkiego, chciałem bowiem uniknąć zajmowania się kliniczną perspektywą patologii. Uświadomiłem sobie, że w duchowości Chiary Lubich ${ }^{2}$, w jej charyzmacie jedności, znajdują się wątki, których szukałem, aby poddać je refleksji oraz przeszczepić do życia osobistego, społecznego i zawodowego, a przez to krytycznie osądzić i zweryfikować ich znaczenie i funkcjonalność dla jednostki oraz relacji społecznych. Należą do nich: konkretna, uniwersalna miłość do każdego człowieka, wzajemność w tym obopólnym szacunku oraz jedność w różnorodności - jedność, która z perspektywy chrześcijańskiej ujawnia obecność Jezusa między dwiema lub więcej osobami. Zadałem sobie pytanie, jakie znaczenie miałoby dla psychologii przeniesienie tych elementów i konkretna aplikacja na grunt relacji międzyludzkich i społecznych. Wyczuwałem, że może ono przynieść pozytywną rewolucję.

Chciałem zbadać najgłębsze wymiary każdego z tych elementów, aby uczynić je widocznymi, namacalnymi, konkretnymi, jak również odkryć i sprawdzić możliwe skutki, konsekwencje wprowadzenia ich w życie. Zdałem sobie równocześnie sprawę, że moje badania nie mogą odnosić się jedynie do zjawiska widzianego z zewnątrz. Chciałem zagwarantować całościowe wyniki badań, które zostałyby uzyskane ze studium, ujęć teoretycznych, ale także z życia i doświadczenia, z użyciem metodologii PAR (Participation-Action-Research), w tamtym czasie wciąż mało rozumianej i używanej. Był to okres, w którym naukowa akredytacja metodologii jakościowej dopiero się rozpoczęła.

${ }^{1}$ Paul Musse, Nancy Eisenberg, The Roots of Caring, Sharing, and Helping: The Development of Pro-Social Behavior in Children (San Francisco: W. H. Freeman, Nation at Risk, 1977).

2 Doctorat honoris causa w dziedzinie pedagogiki nadany przez University of America w Waszyngtonie: Chiara Lubich, „Lezione per la laurea honoris causa in Pedagogia, Washington, 10 novembre 2000", Nuova Umanità 135-136 (2001/3-4): 341-352. 
W 1983 r. w pałacu sportowo-rozrywkowym w Rzymie w centrum kompleksu EUR zebrało się 12000 osób, aby formalnie zainaugurować Ruch Nowej Ludzkości. Było to niezwykle istotne, aby wziąć udział w tym, co $\mathrm{z}$ biegiem lat stanie się LIPA (Laboratorio de Investigación Prosocial Aplicada - Laboratorium Stosowanych Badań Prospołecznych) na Uniwersytecie Autonomicznym w Barcelonie ${ }^{3}$.

W pierwszych latach i po wyjeździe do San Francisco w ramach stypendium naukowego i na zaproszenie profesora Mussena zapoznałem się z pionierskimi doświadczeniami wykonanymi w niektórych szkołach w San Francisco, które ogniskowały swoją pracę na zagadnieniach prospołecznych, i rozpocząłem budowę projektu badawczego (Development Project). Ten projekt kierował naszymi pierwszymi poszukiwaniami, odnoszącymi się do uwarunkowań edukacyjnych Katalonii i pierwszymi programami w szkołach na obrzeżach Barcelony, wprowadzanymi na wniosek i przy wsparciu rządu Generalitat de Catalunya, które traktowały edukację jako pionierską przestrzeń $\mathrm{w}$ aplikowaniu prospołeczności (termin utrwalił się w językach kastylijskim i katalońskim, gdy jeszcze w USA nie przyjął formy przymiotnikowej).

Z biegiem czasu LIPA przyczyniło się do przekształcenia w kilkunastu językach przymiotnika „prospołeczny” w formę rzeczownikową „prospołeczność” i w końcu w czasownik ,prosocjalizacja”. Zbiegło się to w czasie $\mathrm{z}$ wypracowaniem definicji, której potrzebowaliśmy dla scharakteryzowania tego, co postrzegaliśmy jako innowacyjne w naszej pracy i będące wynikiem zarówno akademickiej teorii, jak i zastosowania w życiu oraz relacjach między osobami budującymi LIPA oraz tymi, którzy tworzyli swoją własną grupę. Tak więc prospołeczność stała się centrum i motorem zarówno badań, jak i ducha LIPA.

\section{Definicje, kategorie i katalogi działań prospołecznych}

\subsection{Definicja}

W naszym zespole LIPA na pierwszym poziomie definicyjnym zachowania prospołeczne rozumieliśmy jako:

${ }^{3}$ LIPA: Laboratorio de Investigación Prosocial Aplicada (Applied Prosocial Research Laboratory) z Universidad Autónoma w Barcelonie. LIPA to multidyscyplinarny i międzynarodowy zespół tworzony przez niektórych profesorów UAB i kilku zewnętrznych specjalistów. 
Te zachowania, które bez poszukiwania nagród zewnętrznych lub materialnych faworyzują inne osoby lub grupy zgodnie z ich kryteriami lub obiektywnie pozytywnymi celami społecznymi, zwiększając prawdopodobieństwo uzyskania pozytywnej wzajemności w jakości i solidarności w wynikających z nich relacjach międzyludzkich lub społecznych, chroniąc tożsamość, autonomię, kreatywność i inicjatywę zaangażowanych w nie osób lub grup ${ }^{4}$.

Istotnym wymiarem tej definicji, która była już obszernie rozwijana we wcześniejszych publikacjach ${ }^{5}$ i która została ostatnio zaadaptowana w niepublikowanych pracach ${ }^{6}$, jest podkreślenie w przeciwieństwie do innych definicji fundamentalnego kryterium, konstytuującego zachowania prospołeczne, którym jest kryterium odbiorcy, polegające na tym, że on owe zachowania akceptuje i jest z nich zadowolony.

Moglibyśmy podsumować, że działaniem prospołecznym jest takie działanie, które obdarowuje innego tak, jak chce on być obdarowany; jest to idea kontrastująca z koncepcją działań pomocowych (,, help” actions), które nie uwzględniają ,,prospołecznego" modelu uwarunkowań, potrzeb, tożsamości i kultury odbiorcy.

Włączając rzeczywistość innego do definicji prospołeczności, unika się ryzyka uznania za prospołeczne tych działań, które bardziej ranią innego, niż czymkolwiek go obdarzają: np. czyniąc w dobrej intencji łaskę, której odbiorca nie docenia po prostu dlatego, że to działanie jemu nie pomogło; albo dlatego, że skutkuje ono powstaniem relacji zależności; albo dlatego, że chęć pomocy prowadzi w sposób niezamierzony do poczucia u odbiorcy niższej wartości.

${ }^{4}$ Robert Roche, Hacia una teoria de prosocialidad Lipa (Barcelona: Universidad Autonoma de Barcelona, 2014), 19 [praca niepublikowana].

5 Robert Roche, „Violencia y Prosocialidad: un programa para y descondicionamiento frente a la violencia en la imagen y para la educación de los comportamientos prosociales". W: Que Miras? (Valencia: Publicaciones de la Generalitat Valenciana, 1991), 291-313; Robert Roche, Psicología y Educación para la prosocialidad (Buenos Aires: Ciudad Nueva, 1997); Robert Roche, „L'educazione alla prosocialità come ottimizzatrice della salute mentale e della à nelle relazioni sociali", Nuova Umanità 21/121 (1999): 29-48; Robert Roche, Inteligencia prosocial: educación de las emociones y valores (Cataluña: Servei de Publicacions Universitat Autònoma de Barcelona, 2004); Robert Roche, Educacion Prosocial de las emociones, valores y actitudes positivas para adolescentes en entornos familiares y escolares (Barcelona: Blumes, 1998); Robert Roche, Prosocialidad: Nuevos desafios. Metodologías y pautas para una optimización creativa del entorno (Buenos Aires: Ciudad Nueva, 2010).

${ }^{6}$ Roche, Hacia, 19. 
Prospołeczność z tej perspektywy można nazwać zaraźliwą, łatwą do naśladowania i ułatwiającą naukę. Należy powiedzieć, że działaniem prospołecznym jest bardzo proste działanie, dostępne dla każdego i dlatego jest łatwo rozpoznawalną i ułatwiającą przestrzenią nauki.

Wszystkie proponowane działania składają się z następujących elementów:

- pewien stopień kreatywności;

- asertywność;

- koszt, ważny w osobistym odczuciu zdolności i proaktywności;

- pozytywne wyniki lub korzyści;

- określona pewność co do funkcjonalności działania;

- informacje zwrotne dotyczące znaczenia;

- pozytywne wzmocnienie przekonań dotyczących dobroci, pozytywnych relacji międzyludzkich;

- wysokie prawdopodobieństwo osiągnięcia sukcesu, co zwiększa prawdopodobieństwo powtórzenia.

Być może są to ludzkie zachowania: bardziej powszechne i dostępne dla każdej osoby, z większymi możliwościami osiągnięcia sukcesu, łatwiejsze do realizacji w interpersonalnym czasie i przestrzeni.

\subsection{Klasy lub kategorie prospołeczności}

Zidentyfikowaliśmy 10 klas lub kategorii działań prospołecznych LIPA. Są to: 1) pomoc fizyczna; 2) opieka; 3) dawanie i dzielenie się; 4) pomoc słowna; 5) słowne pocieszenie; 6) wsparcie i pozytywna ocena drugiego człowieka; 7) uważne słuchanie; 8) empatia; 9) solidarność; 10) pozytywna obecność i zjednoczenie.

\subsection{Katalogi działań prospołecznych}

Efektem uporządkowania działań prospołecznych przez LIPA jest „lista zachowań prospołecznych operacyjnych, zgodnie z kategoriami LIPA, które są bardziej pożądane i możliwe w określonym kontekście lub zakresie, przygotowana przez naukowca na podstawie kryteriów wszystkich osób zaangażowanych w wyżej wymieniony obszar"7. Aby osiągnąć ten po-

\footnotetext{
${ }^{7}$ Robert Roche, L'intelligenza prosociale (Trento: Erikson, 2002).
} 
ziom konkretyzacji i operacjonalizacji, zaproponowano procedurę badania w działaniu (Participatory Action Research) w celu zdefiniowania listy pożądanych i wykonalnych zachowań prospołecznych w dowolnym systemie, zgodnie z potrzebami i spostrzeżeniami aktorów zaangażowanych w konkretny kontekst ${ }^{8}$.

Metodologia tworzenia uwarunkowanych kontekstualnie list zachowań prospołecznych okazała się przydatnym narzędziem do projektowania planów prospołecznej optymalizacji dla każdego zakresu, a także jest doskonałym narzędziem do diagnozy i oceny poziomu prospołeczności grup lub zespołów roboczych, np.: wydziałów organizacji, firm, kolegium nauczycieli, społeczności sąsiedzkich, klubów sportowych, supermarketów lub dyskotek.

\section{Wielorakie źródła doświadczeń}

W 1994 r. miało miejsce wydarzenie, które nadało naszej pracy nieoczekiwany wymiar. W tym czasie reżim polityczny w starej Czechosłowacji upadł i państwo to podzieliło się na dwie części. Władcy obu próbowali znaleźć humanistyczny fundament edukacji społecznej, który zastąpiłby ten stanowiony przez marksizm, a równocześnie tworzyłby możliwość połączenia doświadczeń nauczycieli, którzy wykładali filozofię marksistowską z doświadczeniami zwolenników innych filozofii, np. chrześcijańskich. $\mathrm{Na}$ Słowacji postanowiono więc, za radą doradcy rządowego Ladislawa Lencza, zorganizować nauczanie etyki, akceptowalnej dla wszystkich orientacji i wprowadzanej we wszystkich klasach obowiązkowej edukacji. Nasze teksty na temat prospołeczności zostały zaliczone do pierwszych tekstów etyki wychowawczej (Eticka Vichova $)^{9}$. Zostaliśmy powołani przez wiceministra do uczestnictwa w formowaniu pierwszych trenerów (1994-1997).

Dzisiaj, po prawie 25 latach, jest już ponad 3000 nauczycieli i tysiące studentów, którzy zostali przeszkoleni w tym projekcie. Na Słowacji istnieją katedry na pięciu wydziałach z setkami wyspecjalizowanych studentów. Również w Czechach uczestniczyliśmy w różnych formacjach i kursach dla niektórych stopni, w Pradze (13-16 listopada 2003 r.) i Kromeriz. Istnieją prace doktorskie na temat edukacji prospołecznej w Republice Czeskiej.

${ }^{8}$ Roche, Prosocialidad.

9 Ladislav Lencz, „The Slovak Ethical Education Project”, Cambridge Journal of Education 3/24 (1994): 443-451; Robert Roche, Eticka vychova (Bratislava: Orbis Pictus Istropolitana, 1992). 
Konieczne jest posuwanie się naprzód (nie tylko w badaniach) w upowszechnianiu i przekazywaniu pionierskich i udanych doświadczeń, które okazały się innowacyjne, zrównoważone i możliwe do przeniesienia do innych kontekstów. Przykładem tego mogą być szkolne i obywatelskie programy edukacyjne oparte na prospołeczności, włączające ją do nauczania etyki w słowackim systemie edukacyjnym ${ }^{10}$.

W trakcie rozwijania naszego projektu utrzymywaliśmy częsty kontakt z Chiarą Lubich. Zawsze odpowiadała na nasze listy i komunikaty z wynikami i konkluzjami z badań, przekazując słowa pochwały i zachęty.

LIPA było zawsze centrum otwartym na dialog ze wszystkimi przekonaniami. W rzeczywistości dyrektorami ośrodka zostają osoby związane zarówno z koncepcją chrześcijańską, jak i z innymi poglądami. Gdy ja byłem pytany o moje osobiste inspiracje, zawsze odpowiadałem, że inspiracją dla mnie był akademicki przekład duchowości Chiary Lubich, hipotetyczne podejście do niej, poszukiwanie, krytyka i weryfikacja z naukowej i akademickiej perspektywy.

Od samego początku praca nad zbudowaniem teoretycznego modelu prospołeczności w wielu obszarach wykazuje naukowo, że systematyczne i konkretne programy prospołeczności mogą być właściwymi rozwiązaniami wielkich problemów współczesnego człowieka. Wykazując znaczenie, funkcjonalność, a nawet skuteczność owego modelu, nie podając jego pochodzenia, staramy się tłumaczyć i wcielać charyzmat jedności w sposób teoretyczny, a jednocześnie konkretny i systematyczny na polu naukowym i akademickim.

\section{LIPA współcześnie}

LIPA jest ośrodkiem badań, szkoleń, doradztwa i rozpowszechniania prospołeczności w odniesieniu do relacji międzyludzkich, grupowych i społecznych, co sprawia, że zawodowe i osobiste projekty jej członków przenikają się, wpływają na styl życia, pracę zespołu oraz relacje z lokalnymi ekspertami, z którymi pracują.

Zespół LIPA opiera swoje interwencje na epistemologicznej strukturze badań w działaniu (Participatory Action Research) oraz na wartościach reprezentatywnych dla prospołeczności (godność osoby ludzkiej, podkreślanie wartości, szacunku i miłości do wszystkich ludzi). LIPA działa na polu nauko-

${ }^{10}$ Lencz, „The Slovak”; Roche, Eticka vychova. 
wym, akademickim, społecznym i biznesowym poprzez badania stosowane, szkolenia, projekty interwencyjne, publikacje naukowe i informacyjne.

Od prawie 30 lat bada i stosuje programy optymalizacyjne w zakresie podstawowych zmiennych, mających wpływ na rozwój procesu komunikacji, szczególnie tych, które mogą mieć kluczowe znaczenie dla skutecznej i zadowalającej komunikacji, nazywanej komunikacją o jakości prospołecznej (Prosocial Quality Communication) ${ }^{11}$. Poprzez transfer wiedzy w trakcie wszystkich opracowywanych projektów LIPA pokazało, że promocja komunikacji o jakości prospołecznej, za pośrednictwem szkoleń i specjalistycznej metodyki pracy, bezpośrednio wpływa na satysfakcję, sukces lub uregulowanie relacji międzyludzkich i wewnątrz organizacji ${ }^{12}$.

$\mathrm{W}$ ciągu ostatnich 10 lat rozszerzaliśmy sprawdzone metody interwencji na kolejne środowiska, w których funkcjonują osoby dorosłe, szczególnie te o wysokim stopniu złożoności: szpitale, więzienia, organizacje biznesowe, dzielnice miast, świat polityki, uniwersytety i inne.

Jako zespół, wraz z uniwersytetami w Europie i Ameryce Łacińskiej oraz specjalistami z różnych dziedzin, uczestniczyliśmy w około 15 projektach europejskich dotyczących przekazu nastawień prospołecznych, oferując metodykę interwencji w problemy społeczne, takie jak: przerywanie nauki szkolnej (projekt MOST, 2011), prospołeczność w dziedzinie opieki zdrowotnej (projekt CHANGE, 2010) oraz w branży turystycznej (Project Train to Change, 2013) lub w szkolnictwie wyższym w celu poprawy poziomu sprawiedliwości w dostępie do rynku pracy w Ameryce Łacińskiej (Projekt SPRING, 2012).

Obecnie badania dotyczące prospołeczności podejmowane są nie tylko w psychologii, ale także w dziedzinach z zakresu ekonomii, zdrowia, edu-

${ }^{11}$ Gloria Pilar Escotorín Soza, Comunicación interpersonal de calidad prosocial: hacia una definición del concepto y síntesis teórica actualizada del modelo aplicable a díadas en contextos organizacionales (Bellaterra: Universidad Autónoma de Barcelona, 2008); Robert Roche, „Comunicación de calidad en la pareja y en las relaciones interpersonales”, Familia y Sociedad 1 (1994): 363-367; Robert Roche, Psicología de la Pareja y de la Familia Analisis y Optimización (Bellaterra: Servei de Publicacions Universitat Autònoma de Barcelona, 2006); Robert Roche, Esther Arozarena, ,Algunas dimensiones de la comunicación de calidad en la pareja", Actas de las IX Jornadas Españolas de Terapia Familiar 18 (1988): 425-445; Robert Roche, Reinaldo Martínez-Fernández, „Efectos de un programa de entrenameinto prosocial en la comunicación de pareja”, Revista de Tarapia Sexual y de Pareja 24 (2006): 30-50.

12 Robert Roche, Prosocialidad; Pilar Escotorín Soza, Robert Roche, Cómo y por qué prosocializar la atención sanitaria: reflexiones, desafíos y propuestas. Conclusiones del Proyecto Europeo CHANGE (La Garriga: Fundación Martì L'Humà, 2011). 
kacji, polityki i neuronauk ${ }^{13}$. Wzrasta zainteresowanie badaniem tej kwestii jako zjawiska, do którego odnosi się rzeczownik ,prospołeczność”" ${ }^{14}$, jako procesu opisywanego przez czasownik ,,prosocjalizować”, używany do ujęcia metodyki interwencji ${ }^{15}$, a nade wszystko jakości rzeczywistości, do wyrażenia której używa się przymiotnika „prospołeczny” i do której odnosi się większość publikacji, przymiotnika oznaczającego właściwość: prospołeczne zachowanie, prospołeczna komunikacja, prospołeczne myślenie, prospołeczna inteligencja, prospołeczna empatia, prospołeczne działanie.

Znaczące i wymagające podkreślenia jest to, że LIPA promowało i kierowało kilkunastoma pracami doktorskimi, m.in. jedną poświęconą Jakości komunikacji prospołecznej (Prosocial Communication Quality) ${ }^{16}$, dwoma na temat Prospolecznego kierownictwa (Prosocial Leadership) ${ }^{17}$ jako alternatywy dla kierownictwa transakcyjnego i transformatywnego.

W ramach rozpowszechniania i udoskonalania modelu prospołeczności, wypracowanego przez LIPA, prowadzono kursy, seminaria, warsztaty, programy w ponad 20 miastach włoskich, Hiszpanii, Słowacji, Czechach, Chorwacji, Macedonii, na Ukrainie, Litwie, w Niemczech, Rumunii, Austrii, Argentynie, Peru, na Kubie, w Chile, Brazylii, Meksyku, Kolumbii, Boliwii, Ekwadorze, Wenezueli.

Zagadnienie prospołeczności jawi się w badaniach naukowych jako temat z długą historią, a termin „działanie prospołeczne” zaczyna być dobrze

13 Gloria Pilar Escotorín Soza, Prosocial Communication Inquiry in collaboration with gerontology health professionals. Consulta sobre comunicación prosocial con profesionales socio-sanitarios del ámbito gerontológico (Universidad Autonoma de Barcelona. Bellaterra: 2013).

${ }^{14}$ Robert Roche, „Violencia”, 291-313; Robert Roche, Psicología y Educación para la prosocialidad (Barcelona: Universitat Autònoma de Barcelona, 1995); Bernadette P. Luengo Kanacri, Concetta Pastorelli, Nancy Eisenberg, Antonio Zuffianò, Gian Vittorio Caprara, „The Development of Prosociality from Adolescence to Early Adulthood: The Role of Effortful Control", Journal of Personality and Social Psychology 3/81 (2013): 302-312; Gian Vittorio Caprara, Guido Alessandri, Nancy Eisenberg, „Prosociality: The Contribution of Traits, Values, and Self-Efficacy Beliefs", Journal of Personality and Social Psychology 6/102 (2012): 1289-1303.

${ }^{15}$ Escotorín Soza, Roche, Cómo y por qué.

${ }^{16}$ Escotorín Soza, Prosocial Communication.

17 Maria Carme Cirera Amores, Estudio cualitativo del liderazgo prosocial: El Proyecto SPRING (Bellaterra: Universidad Autónoma de Barcelona, 2015); Ana Esther Bedoya Rodriquez, Del liderazgo transformacional al liderazgo prosocial: Evidencias obtenidas en la Dirección de organizaciones sanitarias catalanas (Bellaterra: Universidad Autónoma de Barcelona, 2015). 
znany, a nawet coraz powszechniej wykorzystywany przez badaczy z różnych dziedzin. Kategorie te są również powiązane jako słowa kluczowe w wyszukiwarkach internetowych, takich jak Google.

Paradoks polega na tym, że chociaż społeczność naukowa wykazała korzyści płynące z działań prospołecznych, ciągle dostrzegalna jest przepaść między tym, co badania ukazały jako korzyść dla praktyki społecznej, a tym, co jest wprowadzane i praktykowane w kulturze organizacyjnej różnych grup społecznych.

\section{PROT (Prosocial Optimization Theory - teoria optymalizacji prospołecznej)}

W ostatnich latach w LIPA staraliśmy się uporządkować charakterystykę prospołeczności, odwołując się do teoretycznych studiów tego zagadnienia, badań eksperymentalnych oraz profesjonalnego zastosowania. Wypracowany model określamy jako PROT, czyli teoria optymalizacji prospołecznej.

Nazwa przypisana do tej teorii odzwierciedla nazwę i proces rozwoju Wydziału Psychologii Autonomicznego Uniwersytetu w Barcelonie trwający ponad 32 lata. Okres ten obejmuje 10 lat ,inkubacji” od standardowej definicji anglosaskiej (od 1982 r.) przez kolejne 22 lata (do 2014 r.) aż do powstania jednej z najnowszych prac akademickich zawierających tezy Glorii Pilar Escotorín Sozy ${ }^{18}$. W tym czasie wyznaczono oryginalną i własną koncepcję na podstawie badań, a także metodyki stosowanej w nauczaniu psychologii w Autonomicznym Uniwersytecie w Barcelonie w latach 1994-2000 (Optymalizacja rozwoju społecznego: uczenie się zachowań prospołecznych) oraz 2000-2011 (Optymalizacja prospołeczna).

Obecna była ona w tematach prac dyplomowych studentów studiów licencjackich i doktoranckich w dziedzinie psychologii, znających tę koncepcję i doceniających ją. Wiemy, że wielu z nich wykorzystało ją w swojej pracy, dlatego jest ona rozpowszechniana w całym naszym kraju. Od 1994 r. studia kończyło średnio około 65 studentów rocznie, co daje w sumie około 1300 studentów (obecnie większość z nich to wykwalifikowani psychologowie).

W teoretycznych i praktycznych zajęciach z przedmiotu, wykorzystując metodologię badań w działaniu, zbadano teorię, podjęto praktyki aplikacyjne i interwencyjne z wykorzystaniem innowacyjnych technik, w których

${ }^{18}$ Escotorín Soza, Prosocial Communication. 
studenci stali się prawdziwymi żyjącymi laboratoriami jako agenci i prospołeczni operatorzy, zarówno w sferze osobistej, jak i zawodowej, opracowując projekty interwencyjne w ściśle określonych kontekstach.

PROT został skonstruowany jako model teoretyczno-aplikacyjny wywodzący się z definicji prospołeczności opracowanej na trzech poziomach: pierwszy poziom - koncepcyjny lub teoretyczny (co jest rozumiane jako prospołecznośćc ${ }^{19}$ ), drugi poziom ogranicza tę definicję do 10 kategorii operacyjnych $^{20}$, trzeci zaś precyzyjnie i przy ograniczonej metodologii definiuje i adaptuje 10 kategorii do każdego kontekstu w zróżnicowany sposób ${ }^{21}$. Te trzy poziomy w niniejszym artykule są również zdefiniowane jako metodyka interwencji.

Omawiany model odnosi się do ośmiu wymiarów:

- optymalizacja;

- prospołeczność skupiona na odbiorcy i jego kontekście;

- wzajemność, ogólna horyzontalność i cykliczność;

- empatia i jedność;

- odpowiedzialność, zaangażowanie oraz działanie;

- badanie w działaniu;

- operatywna kategoryzacja działań prospołecznych;

- zestawienie działań prospołecznych przez odbiorców-beneficjentów.

\section{Zastosowanie w przedszkolu}

\subsection{Kluczowy moment socjalizacji}

Pytania, które może zadać wychowawca lub nauczyciel, dotyczą początków procesu socjalizacji między rówieśnikami oraz kwestii jak najlepszego radzenia sobie z wyzwaniami tego okresu. Intryguje zwłaszcza problem tych aspektów rozwoju danej grupy wiekowej, które dotykają zdrowia i sprawności osoby, ale także rozwoju wzajemnych relacji pomiędzy zdrowymi ludźmi i osobami z nimi współpracującymi, a przez to przyczyniają się do osiągnięcia i zbliżenia do utopijnej wizji bardziej pokojowego i harmonijnego społeczeństwa.

\footnotetext{
19 Roche, Eticka vychova; Roche, Prosocialidad.

20 Roche, Eticka vychova; Roche, Prosocialidad.

${ }^{21}$ Escotorín Soza, Roche, Cómo y por qué.
} 
Nowe ujęcia postrzegają dziecko jako protagonistę własnego uczenia się, poprzez wychowanie do wartości, poprzez rozwój krytycznego i twórczego myślenia, z wykorzystaniem zabawy jako źródła uczenia się i projektów uczenia się jako globalnej i interdyscyplinarnej metody działania. Niewątpliwie wszystkie te silne idee zmieniają sens i kierunek edukacji, ale co stanie się, jeśli do wartości społecznych, które promują, dodamy wartość „mojego drugiego ja”? Model prospołeczny wydaje się budować w nich równowagę. Jednakże te metodologie i modele edukacyjne odnoszą się do starszych dzieci, być może ze względu na olbrzymie braki, jeżeli chodzi o skuteczne metody pracy z dziećmi dwuletnimi. To jednak w tym okresie życia pojawia się u dzieci w sposób naturalny zainteresowanie rówieśnikami. Znajdują się zatem na początkowym etapie horyzontalnych procesów socjalizacyjnych, w których nie zdobyli jeszcze znacznej liczby umiejętności ${ }^{22}$. Dlatego też uczenie się zachowań prospołecznych w tym okresie zarówno ma wielką wartość dla budowania osobowości, jak i nabywa profilaktycznego charakteru ze względu na uczenie się harmonijnego współistnienia ${ }^{23}$.

Poniższy przypadek przedstawiono jako próbę badań w działaniu (Participation - Action - Research) w grupie 15 dzieci w wieku dwóch lat.

\subsection{Przypadek J. G.}

J. G. jest dzieckiem, które ma duże zdolności językowe. Od najmłodszych lat buduje pełne zdania bez popełniania błędów gramatycznych. Używa rodzajników i poprawnie odmienia czasowniki. Potrafi wyrazić życzenia, uczucia i myśli. Rozumie również i wysyła komunikaty, wykazując wysoki poziom zrozumienia, internalizacji i asymilacji, co widać w codziennych działaniach. Ma też świetne rozeznanie w otaczającej go przestrzeni, gdzie bawi się różnymi przedmiotami i buduje proste struktury, które jak się wydaje, zaplanowało w swoim umyśle. Z łatwością operuje liczbami i kwotami $\mathrm{i}$ jest $\mathrm{w}$ stanie rozpoznać słowa, które zostały podane $\mathrm{w}$ trakcie procesu nauczania. Dobrze odnajduje się w relacjach społecznych. Bawi się ze swoimi kolegami z klasy, chociaż woli czynić to samemu. Komunikuje się z nimi,

${ }^{22}$ Ellen McGinnis, Arnold Goldstein, „Programa de Habilidades para la Infancia Temprana", http://www.oei.es/historico/inicial/articulos/habilidades_infancia.pdf [dostęp: 20.02.2018].

23 Roche, Psicología y Educación. 
odpowiada na pytania i uczestniczy w spontanicznych dialogach, które rodzą się między nimi. Jest dzieckiem, które ma zaufanie do rutynowych czynności, ale nie jest zbyt elastyczne, aby się zmienić.

Problemy, które pojawiły się:

- nie pozwala innym dzieciom uczestniczyć w jego zabawie;

- ono zbiera wiele przedmiotów do zabawy i trzyma je tak, aby nikt mu ich nie zabrał;

- reaguje płaczem i ściga dzieci, które zabrały jedną z jego zabawek, chąc ją odebrać.

Cele do osiągnięcia:

- współdziałanie z innymi dziećmi w czasie swobodnej zabawy;

- dzielenie się przedmiotami z dziećmi;

- używanie werbalnych komunikatów jako środka rozwiązywania problemów.

Hipotezy:

- egocentryczność uniemożliwia dzieciom łatwe dzielenie się (H1);

- faza modelowania sprzyja wspólnemu uczeniu się (H2);

- współpraca w różnych kontekstach (rodziny i szkoły) sprzyja bardziej skonsolidowanemu uczeniu się zachowań społecznych (H3).

Zmienne:

- reakcja na płacz i napady złości (V1);

- zgoda na uczestnictwo innych dzieci w zabawie (V2);

- dzielenie się przedmiotami (V3).

Metody wprowadzania prospołecznej zdolności do dzielenia się:

- Uczenie się przez obserwację: to, co nauczyciel oraz inne dzieci robią oraz myślą, będzie używane jako środek uczenia się. Aby wspomóc proces uczenia się, zaproponujemy modele poprawnych zachowań i połączymy je w taki sposób, aby poprzez wywoływanie przyjemnych sytuacji wspomóc proces naśladowania innych.

- Technika zbliżenia: cel będzie osiągany stopniowo, tak aby pożądane zachowanie było przyswajane krok po kroku. By tak się stało, rozłożymy cel na mniejsze cele i będziemy wzmacniać pozytywne zachowania zbliżające do niego.

\subsection{Koordynacja działań rodziny i szkoły}

Aby wzmocnić efektywność procesu uczenia, pożądane jest zaangażowanie rodziny. Aby je uzyskać, rodzice będą proszeni o wsparcie w progra- 
mie interwencyjnym, jak również podkreślane będzie znaczenie ich współpracy oraz włączanie do programu trosk rodziny i jej planów.

Proces nauczania-uczenia się będzie rozwijany poprzez cztery podstawowe techniki:

- modelowanie: dziecko będzie osiągało cele poprzez obserwację zachowania nauczyciela i kolegów z klasy; będzie dążyć się do wypracowania takich zachowań, które będą naturalne i spontaniczne;

- odgrywanie ról: poprzez organizowanie naturalnych sytuacji dziecko zacznie postrzegać umiejętności, nad którymi pracuje, jako zachowania i nastawienia o większym znaczeniu;

- informacja zwrotna: będzie oparta na społecznym wzmocnieniu, takim jak pochwała i aprobata; pierwsze doświadczenia zostaną wzmocnione poprzez technikę „kontrakt punktowy” (point's contract), której celem będzie likwidacja wzmocnienia materialnego i utrzymanie wzmocnienia społecznego;

- przeniesienie: uczenie się zachowań rozpocznie się w klasie szkolnej, w zależności od odpowiedzi uczniów, podobne sytuacje do tych doświadczanych w klasie będą kreowane w innych środowiskach w kontekście szkolnym i rodzinnym.

\subsection{Etapy uczenia się społecznej umiejętności „dzielenia się"}

Zorganizowano spotkanie z rodziną J. G., aby poinformować ją o programie modyfikacji zachowania oraz ustalić wspólny plan działania, mający wzmocnić pracę w szkole. W szkole program rozpoczyna się od „kręgu przyjaciół”, współpracy, która została podjęta w klasie na kilkanaście tygodni. W tym kręgu podkreślamy, że J. G. czasami złości się, więc zamierzamy mu pomóc, aby zawsze było szczęśliwe, używając zwrotu: „J. nie ma sprawy. Podzielmy się wszystkim. Jeden dla ciebie, jeden dla mnie".

Pierwszy tydzień. Dla dzieci zostanie opracowany plan, tak aby mogły bawić się razem, dzieląc się zabawkami:

1. W tym celu dzieci będą współpracować w podstawowych, utworzonych już w klasie grupach, które otrzymają konkretne przedmioty.

2. Nauczyciel skupi się na zespole, do którego należy J. G., i będzie działał tak, jak robią to inne dzieci, prowokując je w ten sposób do zachowania, które ma zostać zmodyfikowane; gdy ono wystąpi, nauczyciel pokaże pożądane zachowanie i będzie pełnił funkcję modelu uczenia się. 
3. W miarę upływu tygodnia nauczyciel będzie coraz bardziej angażował członków zespołu J. G., najpierw wzmacniając dobre zachowania, a następnie, jako przewodnik, zachęcając do uczenia się na podstawie zachowań innych dzieci jako modeli.

4. W tym czasie rodzina zostanie proszona o podjęcie tego samego przedsięwzięcia; podczas spotkania z rodzicami ustalane są wytyczne dla gry, która zostanie przeprowadzona w domu. Ojciec i matka staną się towarzyszami zabawy J. G. Kluczem będzie działanie na wzór innych dzieci, bez zwracania uwagi na to, co J. G. chce zrobić, ale ze swobodnym wykorzystaniem przedmiotów pozwalających na zrobienie tego, co się chce.

5. Przedmioty zostaną umieszczone w centrum, tak aby każdy mógł mieć do nich dostęp; w ten sposób budowana będzie świadomość, że przedmioty należą do wszystkich; kluczem jest „brać jeden na raz, tylko to, co jest potrzebne, tak aby inni także mogli grać".

Drugi tydzień:

1. Zmieniamy przedmioty i powtarzamy cały proces, aż J. G. zacznie się dzielić, unikając postawy przywłaszczenia i ukrywania przedmiotów;

2. Na końcu organizujemy zabawy polegające na odgrywaniu ról, w których kreujemy rzeczywiste sytuacje występujące $\mathrm{w}$ grupie, aby pokazać momenty dzielenia się; to wymaga zaangażowania nauczyciela jako obserwatora oraz wykorzystania tabel systematycznej obserwacji do gromadzenia danych (zob. załącznik) ${ }^{24}$.

Trzeci tydzień:

1. Zostanie umożliwione przeniesienie nabytych umiejętności poprzez tworzenie sytuacji podobnych do tych, które występują w klasie.

2. Zaleca się, aby rodzina zaprosiła do domu kilku przyjaciół, tak aby J. G. mogło podzielić się kilkoma swoimi zabawkami (o których samo decyduje). Ważne jest, aby decyzja ta została podjęta przed przyjazdem gości i aby ono z pomocą swoich rodziców przygotowało i zaprezentowało te przedmioty przyjaciołom, którzy do niego przyjdą.

3. Tymczasem w szkole J. G. zostanie zaproszone do realizacji techniki o nazwie „walizka” (suitcase), w ramach której przyniesie i pokaże towarzyszom swoje ulubione zabawki z nastawieniem na podzielenie się nimi. Tę technikę wykorzystywały wcześniej inne dzieci,

${ }^{24}$ Załącznik znajduje się w angielskiej wersji artykułu. 
więc J. G. miało okazję zobaczyć, w jaki sposób zgadzają się na dzielenie się rzeczami, które przyniosły z domu. Zyskało zatem doświadczenie, które jest punktem odniesienia dla modelowania.

Omówiony tutaj proces można zobrazować, odwołując się do załączników dołączonych do niniejszego artykułu. Pierwsza tabela prezentuje dane zebrane $\mathrm{w}$ badaniu poprzedzającym procedurę a następnie prezentowana jest w sposób systematyczny i metodyczny wprowadzona w życie procedura.

\section{Wnioski}

Badania zostały przeprowadzone w grupie dwuletnich dzieci. Należy do niej J. G., dziecko, które ma dużą umiejętność komunikowania się, ale niewielkie kompetencje społeczne, co uwidacznia się podczas koegzystencji w klasie z resztą dzieci.

W wieku dwóch lat ciekawość dotycząca innych dzieci rodzi się spontanicznie. Badanie zostało przeprowadzone ze względu na konieczność funkcjonowania w klasie, a konkretnie - na pojawianie się zachowań, które to zakłócają. Celem było ukazanie, że metodyczne działania, które zostały przedstawione jako istotne, muszą zostać podjęte od razu, w tym przypadku w poziomych strukturach społecznych. Hipotezy i zmienne zostały ustalone na podstawie filozofii społecznego uczenia się i edukacji na rzecz prospołeczności. Mają one na celu podkreślenie znaczenia wizji wczesnej edukacji prospołecznej.

Sformułowane zmienne pokazują ewolucję, która charakteryzuje cały proces i która odpowiada skrupulatnej gradacji celów do osiągnięcia. Kluczem do tego była technika podejścia. W tym przypadku zmienna „reakcja na płacz i napady złości”, która weryfikuje hipotezę o wyraźnym egocentryzmie w tym wieku, wymagała stałego nadzoru ze strony nauczyciela, ustanawiającego mierzalne wytyczne dla czasu zastępowania negatywnych zachowań krótkimi zdaniami, które rozwiązują konflikt itp. Faza modelowania została wsparta przez wspólnotowe uczenie się. Wszystko, co było doświadczane w grupie, w interakcji z innymi dziećmi, nabierało wartości emocjonalnej, która konsolidowała uczenie się na rzecz pojawiania się nowych zachowań, przenoszonych następnie w naturalny sposób do innych kontekstów. Zmienna ,zezwalanie na udział innych dzieci w zabawie” była odkrywana w ramach filozofii życia i wspólnego budowania nowych doświadczeń oraz podczas poszukiwania. Dało się zauważyć nieustanne postępy dziecka na tym polu. 
Bezpieczeństwo zagwarantowane w obrębie klasy lekcyjnej, dzięki podjęciu skrupulatnej pracy nad nawykami i rutynowymi czynnościami, przekształciło pracę grupową w kierowany trening, w którym J. G. był w stanie stopniowo osiągać coraz więcej, co znalazło odzwierciedlenie w dziecięcej samoocenie i koncepcji siebie.

Prospołeczne zachowania są dla dzieci światem do odkrycia w tak wczesnym wieku. Dzięki zabawom, w których odgrywa się role, uczniowie uczyli się zastępować konkretne impulsy generujące konflikt pozytywnymi zwrotami i nastawieniem. Zabawy polegające na odgrywaniu ról były podejmowane w parach. Dwoje dzieci jest najmniejszą grupą społecznego uczenia się. Trening sprzyjał konsolidacji nowych doświadczeń, które spontanicznie pojawiły się podczas zabawy, gdy zauważało się pierwsze oznaki wzajemności.

Wreszcie kluczowe dla całego procesu były współpraca i zaangażowanie rodziny. Jest ona bowiem dla dziecka naturalnym środowiskiem uczenia się, szkoła stwarza możliwości rozszerzenia tego uczenia się przez wspieranie interakcji między dziećmi. Współpraca między oboma środowiskami wspomagała pojawienie się zachowań prospołecznych poza murami szkoły, najpierw w środowisku rodzinnym, gdzie gwarantowano dziecku poczucie bezpieczeństwa i własnej wartości podczas całego procesu, a następnie w relacjach przyjacielskich i na placu zabaw. Fundamentalne w całym procesie uczenia się było stopniowanie doświadczeń.

Z tego względu hipotezy sformułowane w ramach badań zostały potwierdzone w konkretnej formie. Dziecięca frustracja, której powodem jest brak zrozumienia okazywany przez innych w stosunku do jego własnej perspektywy postrzegania świata, jest czymś naturalnym. Odpowiednio dostosowane projekty edukacyjne pomogły J. G. zmienić własne nastawienie i być bardziej otwartym na zmiany. Niezbędne okazało się wsparcie ze strony innych dzieci. Kiedy uczenie się jest prowadzone jedynie w perspektywie wertykalnej (dorosły-dziecko), traci się spontaniczność zapewnianą przez naturalny dla dziecka kontekst: pozostałe dzieci.

Wspólnotowe uczenie się zakłada techniki, które są podstawą kształcenia opartego na modelowaniu. Odgrywanie ról w parach sprzyjało przyswajaniu prospołecznych zachowań, które później pojawiały się w naturalny sposób w dziecięcej swobodnej zabawie, ujawniając pierwsze oznaki wzajemności. Współpraca między rodziną a szkołą była fundamentalnym czynnikiem konsolidacji zachowań. We wczesnym wieku nauka opiera się na doświadczeniach dnia codziennego. Aby dziecko mogło przenieść nowe działania na inne sytuacje, fundamentalną rolę odegrała współpraca rodziny. 
Warto zauważyć, że chociaż w badaniach skupiono się na jednym dziec$\mathrm{ku}$, reszta grupy również z niego skorzystała. Ujawniło się to w komentarzach, jakie sformułowały matki niektórych dzieci z grupy - nie znając bowiem planu działań, pytały, czy pracowano nad tą umiejętnością, ponieważ ich dzieci demonstrowały ją w domu oraz na placu zabaw. Po raz kolejny pokazano, że proces uczenia się, oparty na interakcji i informacji zwrotnej między dziećmi, ma większy zasięg niż ten, który jest wykonywany tylko w pionie.

Istnieje kilkanaście badań, które przeprowadziliśmy w grupie dzieci we wczesnym wieku, pracując nad innymi umiejętnościami. Wszystkie one były oparte na wspólnotowym uczeniu się oraz edukacji prospołecznej jako dwóch biegunach uczenia się we wczesnym wieku zwieńczonego sukcesem. Orientowanie edukacji na osobę i relacje jest tym, co niewątpliwie stanowi prawdziwą innowację w dzisiejszej szkole.

Wprowadzenie tego edukacyjnego modelu do klasy szkolnej przyczynia się do stworzenia bardziej pozytywnego środowiska, które uświadamia dzieciom, że inni posiadają własną inicjatywę. Poziom uczenia się w klasie w wymiarze kognitywnym jest wyższy, ponieważ rozwija się za sprawą emocji, pojawiających się w ramach interakcji społecznych. Samoocena dzieci wzrasta, ponieważ czują się one potrzebne, gdy mogą pomóc kolegom z klasy, i rodzi się wzajemność, która rozwija pozytywne postawy zarówno wobec dzieci, jak i wobec praktyk edukacyjnych.

Ttumaczenie: Jarostaw Horowski

\section{Bibliografia}

Bedoya Rodriquez, Ana Esther. Del liderazgo transformacional al liderazgo prosocial: Evidencias obtenidas en la Dirección de organizaciones sanitarias catalanas. Bellaterra: Universidad Autónoma de Barcelona, 2015.

Caprara, Gian Vittorio, Guido Alessandri, Nancy Eisenberg. „Prosociality: The Contribution of Traits, Values, and Self-Efficacy Beliefs". Journal of Personality and Social Psychology 6/102 (2012): 1289-1303. DOI: 10.1037/a0025626.

Cirera Amores, Maria Carme. Estudio cualitativo del liderazgo prosocial: El Proyecto SPRING. Bellaterra: Universidad Autónoma de Barcelona, 2015.

Escotorín, Soza, Gloria Pilar, Robert Roche. Cómo y por qué prosocializar la atención sanitaria: reflexiones, desafios y propuestas. La Garriga: Fundación Martì L'Humà, 2011. 
Escotorín, Soza, Gloria Pilar. Comunicación interpersonal de calidad prosocial: hacia una definición del concepto y síntesis teórica actualizada del modelo aplicable a diadas en contextos organizacionales. Bellaterra: Universidad Autónoma de Barcelona, 2008.

Escotorín, Soza, Gloria Pilar. Prosocial Communication Inquiry in collaboration with gerontology health professionals. Consulta sobre comunicación prosocial con profesionales socio-sanitarios del ámbito gerontológico. Bellaterra: Universidad Autonoma de Barcelona, 2013.

Lencz, Ladislav. „The Slovak Ethical Education Project”. Cambridge Journal of Education 3/24 (1994): 443-451.

Luengo Kanacri, Bernadette P., Concetta Pastorelli, Nancy Eisenberg, Antonio Zuffianò, Gian Vittorio Caprara. „The Development of Prosociality from Adolescence to Early Adulthood: The Role of Effortful Control". Journal of Personality and Social Psychology 3/81 (2013): 302-312. https://doi.org/10.1111/jopy.12001.

McGinnis, Ellen, Arnold Goldstein. „Programa de Habilidades para la Infancia Temprana". http://www.oei.es/historico/inicial/articulos/habilidades_infancia.pdf [dostęp: 20.02.2018].

Musse, Paul, Nancy Eisenberg. The Roots of Caring, Sharing, and Helping: The Development of Pro-Social Behavior in Children. San Francisco: W. H. Freeman, Nation at Risk, 1977.

Robert, Roche. Hacia una teoria de prosocialidad Lipa. Barcelona: Universidad Autonoma de Barcelona, 2014.

Roche, Robert, Esther Arozarena. „Algunas dimensiones de la comunicación de calidad en la pareja". Actas de las IX Jornadas Españolas de Terapia Familiar 18 (1988): 425-445.

Roche, Robert, Reinaldo Martínez-Fernández. „Efectos de un programa de entrenamiento prosocial en la comunicación de pareja". Revista de Tarapia Sexual y de Pareja 24 (2006): 30-50.

Roche, Robert. „Violencia y Prosocialidad: un programa para y descondicionamiento frente a la violencia en la imagen y para la educación de los comportamientos prosociales". W: Que Miras?, 291-313. Valencia: Publicaciones de la Generalitat Valenciana, 1991.

Roche, Robert. „Comunicación de calidad en la pareja y en las relaciones interpersonales". Familia y Sociedad 1 (1994): 363-367.

Roche, Robert. „L'educazione alla prosocialità come ottimizzatrice della salute mentale e della à nelle relazioni sociali”. Nuova Umanità 21/121 (1999): 29-48.

Roche, Robert. Educacion Prosocial de las emociones, valores y actitudes positivas para adolescentes en entornos familiares y escolares. Barcelona: Blumes, 1998. 
Roche, Robert. Eticka vychova. Bratislava: Orbis Pictus Istropolitana, 1992.

Roche, Robert. Inteligencia prosocial: educación de las emociones y valores. Cataluña: Servei de Publicacions Universitat Autònoma de Barcelona, 2004.

Roche, Robert. L'intelligenza prosociale. Trento: Erikson, 2002.

Roche, Robert. Prosocialidad: Nuevos desafios. Metodologías y pautas para una optimización creativa del entorno. Buenos Aires: Ciudad Nueva, 2010.

Roche, Robert. Psicología de la Pareja y de la Familia Analisis y Optimización. Bellaterra: Servei de Publicacions Universitat Autònoma de Barcelona, 2006.

Roche, Robert. Psicología y Educación para la Prosocialidad. Barcelona: Universitat Autònoma de Barcelona, 1995.

Roche, Robert. Psicología y Educación para la prosocialidad. Buenos Aires: Ciudad Nueva, 1997. 
